\section{Kongelig Antiquarius Thomas Bartholin og den danske stoicisme}

af forskningsbibliotekar, cand.mag. AnneMette Kirkeby

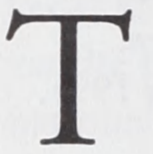

homas Bartholins 700 sider lange hovedværk Antiquitatem Danicarum $^{1}$ udkom i 1689. Det var

skrevet på latin, som var tidens akademiske sprog, og titlen kan oversættes således: “Tre bøger danske antikviteter, om årsagerne til dødsforagten hos danerne, medens de endnu var hedninge, samlet af gamle hidtil uudgivne håndskrifter og mindesmærker”.

Bogen udkom som et resultat af den opgave, som Bartholin havde fået pålagt i sin egenskab af kongelig antikvar, nemlig at tolke og samle danske og islandske skrifter vedrørende danskernes love, sæder og skikke.

Den humanistiske bevægelse i Europa havde skabt forøget interesse for studiet af oldtiden. Oprindelig var det en litterær bevægelse, centreret om studiet af retorik og poetik, men efterhånden omfattede forskningen også andre videnskaber såsom jura, medicin, astronomi, arkitektur, landbrug og militærhistorie. Dette medførte, at klassiske værker om disse emner blev udgivet i tekstkritiske udgaver og oversat.

I Danmark og Sverige var interessen blevet vakt for den islandske litteratur. Her indførtes mængder af islandske middelalderhåndskrifter. Med støtte fra kongemagten ansattes islændinge til at oversætte dem.

Den lærde Olof Verelius i Uppsala oversatte tre islandske sagaer til svensk i samarbejde med islændingen Jonas Rug- man i midten af det 17. århundrede. I Danmark udgav Peder Hansen Resen Snorres Edda og Volvens spådom og Hávamál fra Samunds Edda i 1665. Hvilken mærkeligt nok var den eneste danske udgave i det 17. århundrede.

Ligesom Verelius havde Bartholin en islandsk medhjælper, nemlig den fremragende forsker Arni Magnusson, hvis kritiske evner og store kendskab til den islandske digtekunst havde en stor del af æren for, at Bartholins Antiquitatem Danicarum blev et banebrydende værk.

Det er bygget op som en antologi af islandske tekster af enhver art: sagaer, skjaldekvad og eddadigte. De islandske citater strækker sig ofte over flere sider og er altid ledsaget af latinske oversættelser. En latinsk tekst kæder dem sammen. Her argumenterer Bartholin for sin tese om årsagerne til danernes dødsforagt med mange digressioner og lærde henvisninger til den klassiske litteratur, de europæiske renæssanceforfattere og de nordiske historikere, især Saxo og Torfæus. Bag i bogen findes en liste over det benyttede kildemateriale. Den er på omkring 70 skrifter, idet eddadigtene på Bartholins tid regnedes for ét hele samlet af Sæmundr híns Fróda. Mange af disse islandske digte var ukendte for samtiden, men værkets latinske form gjorde dem kendt og elsket i hele Europa helt op i det 19. århundrede, især i den angelsaksiske verden. Men også blandt de tyske romantikere vurderedes de højt.

Bartholin havde et patriotisk sigte med sin bog, nemlig at vise Europa, at Danmark besad en fortid, som kunne måle sig med den klassiske. Saxo, som var én af Bartholins hovedkilder, var allerede kendt i udlandet takket være Stephanius' berømte værk fra 1645 Note uberiores in 
historiam Danicam Saxonis Grammatici, hvor Saxo for første gang blev behandlet efter samme filologiske metode som de klassiske forfattere. Men der ligger ligeledes et pædagogisk og politisk aspekt mere skjult i bogen.

Beskrivelser af idealstatens opbygning, især den romerske, blev anvendt som forbilleder af absolutismens fyrstemagt. Man ønskede ikke blind imitation, men kritisk at overføre værdier og omskabe dem i overensstemmelse med enevældens ideologi. Således stillede forskerne sig til rådighed for enevoldsmagten for med deres opdagelser at bidrage til opbyggelsen af de nye stater. Allerede 1599 havde en lærd dansk filolog, Niels Krag, udgivet et værk om lov og forfatning, religion, sæd og skik i Sparta De republica Lacedamoniorum libri IV. Og dette værk kan have dannet forbillede for Antiquitatem Danicarum. De historiske kilder i Antiquitatem Danicarum synes at være bedømt ud fra, hvad de afslørede af antropologisk og psykologisk stof snarere end på grund af deres historiske nøjagtighed.

Den svenske forsker Lars Lönnroth har $\mathrm{i}$ et foredrag ved navn "Ideologi och samhällssyn i de isländska sagorna"” påvist, at sagaerne afspejlede et samfund, der var på vej fra et bondesamfund uden centralmagt til et system med et monarki styret af den norske konge gennem ombud, som rekrutteredes fra den gamle høvdingeklasse. De problemer, som behandledes i sagaerne, er i høj grad høvdingeproblemer, som drejede sig om, hvorledes man fik succes i den tids samfund, vandt status, løste diplomatiske og huslige stridigheder, fik held med handelsekspeditioner, og hvorledes man fremstod som en stor mand for eftertiden.

Lars Lønnroth beretter, at en amerikansk forsker, Jesse Byock, har kunnet anvende sagaerne som stof til at vise vejen til succes - "how to gain friends, power and influence" - i sturlungatidens samfund.

En anden amerikansk forsker har benyttet sagaerne som retshistoriske kilder til at kortlægge forskellige typer af juridiske fremgangsmåder inden for rammerne af det indviklede fejde- og processystem.

Bartholin fremhæver de træk i det norrøne litterære materiale, som kendetegnede idealsamfundet, således som man forestillede sig det på hans tid. Det bestod af en stærk centralmagt, en effektiv hær, et fast retssystem og frem for alt en ideologi eller filosofi, som kunne sammenlignes med den romerske stoa.

\section{Neostoicismen}

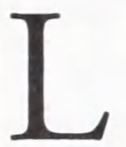
ige siden renæssancens begyndelse havde de stoiske læresætninger haft fremgang. Lærde franskmænd, hvad enten de var calvinister eller katolikker, tog imod de neo-stoicistiske ideer i afsky over det blod, som var blevet udgydt på grund af dogmatiske konflikter.

Guillaume Budé havde skabt et videnskabeligt klima med grobund for den stoiske filosofi. Der var især tæt forbindelse mellem den franske calvinisme og den romerske stoicisme. Calvin selv skrev kommentarer til Senecas De Clementia.

I slutningen af det 16 . århundrede flyttede centrum for den humanistiske forskningsaktivitet fra Frankrig til Nederlandene, og her fremstod den europæiske humanismes ledende skikkelser, hvor især belgieren Justus Lipsius (15471606) var central. Lipsius er blevet kaldt den neostoicistiske filosofis fader. For Lip- 
sius var staten fundamentet, hvor fyrsten, bureaukratiet og hæren måtte være gennemtrængt af den stoiske følelse, som var formet af de romerske værdier.

Lipsius' filosofiske og politiske skrifter fik indflydelse i hele Europa. Hans bøger udkom i oplagstal, som var store for den tid. Han blev læst og værdsat af dem, som havde magt, eller ønskede at forøge den, men også af dem, som havde mistet den og følte savnet. Hans publikum inkluderede konger, hoffolk og deres kritikere. Lipsius' stil gjorde hans værker tiltrækkende for intelligente læsere. Han arbejdede med en tilpasning og kritisk transformation af det antikke tankegods til samtidens brug. Han videregav den romerske stoa og forbandt den samtidig med tanker om borgerpligt, statens væsen, fyrstens og hærens roller. Den europæiske humanisme havde genopdaget Seneca og forsøgte at tilpasse hans filosofi til kristen moral. Med Lipsius' værker toges det afgørende skridt fra det moralfilosofiske til en politisk teoretisk nystoicisme.

Lipsius' filosofiske værk De Constantia (1584), som var gennemtrængt af en stoisk holdning i Senecas ånd, blev udgivet på alle hovedsprogene i det 16 . århundrede. I denne bog var der trøst i nøden til et folk, som var skræmt og forvirret på grund af krige og ødelæggelse i Europa.

Constantia-begrebet blev et symbol på det nye værdisystem, som var baseret dels på romersk moralfilosofi, dels på den stoiske psykologi og dels på praktisk neostoicisme. Fremstillinger af livets ubestandighed og midlertidighed, vore gerningers forgængelighed og tomhed optrådte overalt i kunsten og litteraturen. Mest kendt er de hollandske stillebenmalerier, som havde deres blomstring i 1620erne i den calvinistiske universitetsby Leiden.

Gennem vanitas-symboler som kranier, timeglas og sæbebobler blev mennesket mindet om skæbnens uafvendelighed. Symboler på standhaftigheden (constantia) kan ses i form af søjler, morgenrødmende horisonter og den såkaldte Seneca-buste (som man fejlagtigt anså for at forestille Seneca).

Under Christian 4. var der stærke bånd mellem Holland og Danmark. Kongen ansatte én af Justus Lipsius' elever fra Leiden som professor ved Sorø Akademi. Her fandtes i det 17. århundrede et videnskabeligt miljø, hvor man dyrkede stoikerne, især Seneca. Den adelige Birgitte Thott oversatte Seneca. Marianne Alenius har i en artikel om Birgitte Thott ${ }^{3}$ påvist, at det var Thomas Bartholins berømte fader, lægen med det samme navn, som flere gange opfordrede Birgitte Thott til at udgive Seneca, da læsning af denne klassiske forfatter kunne give styrke til alle danskere. Også Epiktet og Marcus Aurelius blev udgivet af de soranske professorer.

\section{Thomas Bartholins Antiquitatem Danicarum}

7 homas Bartholin den yngre blev født i 1659. Allerede som 14-årig blev han student, og fire år senere blev han designeret professor politices et historiæ patria ved Københavns Universitet. Han havde da allerede forfattet sine første historiske skrifter. I 1684 blev han udnævnt til Kongelig Antiquarius og blev desuden sekretær ved Det kgl. Arkiv, som dengang havde til huse på Rosenborg.

Året efter blev han professor juris og justitssekretær i højesteret. Da var han kun 26 år. 
De mellemliggende år havde han benyttet til studierejser til Europas førende universitetsbyer, bl.a. London, Oxford, Leiden og Paris, således som det var skik blandt unge adelsmænd.

Bartholin var således videnskabsmand med en klassisk uddannelse og samtidig ansat som embedsmand af den enevældige konge.

Selv om Bartholin kunne takke sit familienavn for mange af disse embeder, så kunne kongen næppe have fundet en mere vidende og virkelysten ung mand til at tage vare på fædrelandets oldtidsminder.

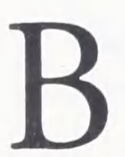

artholins bog om de danske antikviteter er opdelt i tre bøger, som der står i titlen. Hver bog optræder som en helhed og er inddelt i kapitler. Indholdet $\mathrm{i}$ hvert kapitel er gengivet $\mathrm{i}$ korte resumeer.

I første bog beskrives, hvorledes danernes dødsforagt har været genstand for undren gennem tiderne. Allerede Adam af Bremen havde bemærket dette. De gamle nordboer havde ingen kristen tro at støtte sig til, men de optrådte alligevel med stort mod over for døden. Intet var så skammeligt som at $\mathrm{d} ø$ af alderdom. Den store kæmpe Stærkodder klager hos Saxo over, at han snart skal dø i sotteseng ${ }^{4}$. Derfor har han et stykke guld om sin hals, så han kan købe én til at slå sig ihjel.

Det var vigtigt for de gamle kæmper at dø en heltemodig død, mens blodet endnu var varmt. Bartholin påviser, at eftermælet spillede en lige så stor rolle for nordboerne som for de gamle romere. I kap. 7 beskrives de særlige love og forordninger, som gjaldt for de soldater, som ved at flygte var et dårligt eksempel for andre. De skulle udelukkes for al borger- ret. Intet var så ilde anset som at flygte $\mathrm{i}$ kamp. Dette var ligeledes i overensstemmelse med den ultimative betydning af det neostoicistiske constantia-begreb, som det blev formuleret af Lipsius: mange har sejret ved at kæmpe, men ikke ved at flygte.

Hovedemnet i 2. bog er danernes tro på sjælens udødelighed og menneskets liv efter døden. Bartholin drager sammenligninger mellem den nordiske mytologi og den stoiske fysik.

Ifølge den stoiske filosofi bestod alt af de fire elementer ild, vand, jord og luft. Elementerne indgik i et kosmisk forløb, som begyndte med, at urelementerne omdannedes til de andre elementer, som var $\mathrm{i}$ indbyrdes ligevægt, indtil harmonien forstyrredes og processen forløb den modsatte vej. Der herskede uenighed om hos stoikerne om urelementerne ild og vand. Zenon overtog Herakles' forestilling om ilden som urelement, medens Chrysippos overtog Thales' læresætning om vandet som begyndelsen til alt. Seneca skrev: "Ilden er verdens ende, vandet dens begyndelse". Men han beskrev samtidig verdens undergang som en syndflod.

I den nordiske mytologi finder Bartholin mange citater, som beskriver den hellige ild; gudernes hjem Muspell angives i eddaen som lys, hed, luende og brændende, og regnbuen Bifrost har ildens røde farve.

\section{Især i den dunkle Hervaresaga} finder Bartholin en overbevisende overensstemmelse med den stoiske filosofi. Denne saga var blevet udgivet af Olof Verelius i et pragtfuldt folioformat i 1672 med latinsk og svensk oversættelse og udførlige kommentarer. Ifølge Lars Lönnroth, som for nylig har genudgivet sagaen i ny svensk oversættelse ${ }^{5}$, blev denne saga om sværdet 
Tyrfing især anset for at være et vidnesbyrd om den svenske nations storhed $i$ forhistorisk tid. Den svenske konge havde derfor befordret udgivelsen.

Den del af sagaen, som Bartholin citerer, foregår på den danske ø Samsø, hvor skjoldmøen Hervar forklædt som mand forsøger at bemægtige sig sværdet Tyrfing i sin faders gravhøj. Hele øen er omspændt af flammer, men Hervar ænser dem ikke. Hun taler til sin fader, og hendes monolog er i eddapoesi, som anses for at tilhøre den ældste mundtlige tradition. Hervar siger:

“- Bort vill jag hasta härifrån genast, vila i frid i din hög, min far. Mellan två världar tycktes jag sväva medan omkring oss eldarna brann".

Lars Lønnroths oversættelse. ${ }^{6}$

Hervar føler, at hun svæver i luften mellem liv og død, da hun taler med sin far, medens ilden raser.

Luften gav guderne liv, og Gud var ilden, den udødelige ild, som forstod, så og hørte alt. Dette var i overensstemmelse med den stoiske fysik, således som Lipsius fortolkede den ud fra Senecas filosofiske skrifter.

At skabe en verdensforklaring ud fra elementerne kan føres tilbage til den tidlige græske filosofi. Hvilket element, som var det primære, var der uenighed om blandt stoikerne. Bartholin mente, at nordboerne valgte vandet som det element, hvoraf verden blev skabt. I Vølvens spådom findes skabelsesberetningen om Ask og Embla, som blev skabt af to stykker træ, som lå flydende i bølgerne. Bartholin fremsætter den teori, at fordi de første mennesker opstod af havet, overvandtes frygten for dette element. Vandet var det naturlige element for danskerne, da de var omgivet af hav og nødsaget til at lære at beherske havet. Nordboernes religion var således en kampteologi, som skulle indgyde dem mod$^{7}$.

Bartholin har fundet mange tekster, hvor kærligheden til havet udtrykkes, især hos Saxo, f.eks. Haddings rim i 1. bog. Også døden på havet var ærefuld ${ }^{8}$. Bartholin understreger dog ligeledes forskellene mellem folketroen i antikken og i norden. I antikken var man bange for at dø på havet. Det var tilintetgørelse og i strid med forudsigelsen om udslettelsen ved verdensbranden.

I Eddaen fortælles det, at menneskets ånd ikke skulle forsvinde, selv om legemet blev til muld eller til aske. Bartholin refererer den filosofiske diskussion om sjælens udødelighed med citater fra stoikerne og samtidige filosoffer. De stoiske forfattere var ikke enige i denne sag. Ifølge den traditionelle stoiske opfattelse ville mennesket gå under og blive forvandlet til de oprindelige elementer ved verdens undergang. De tidlige stoikere havde den tro, at de gode sjæle levede evigt, medens de onde forgik.

Lipsius' forhold til døden var uafklaret og modsætningsfuldt, ligesom vi finder det hos Seneca. Seneca talte om døden som en fuldstændig tilintetgørelse, men ved siden af denne anskuelse stod en anden, nemlig at døden var en overgang til en bedre tilværelse. Som mange andre klassiske forfattere tog han ikke bestemt stilling til spørgsmålet om et personligt liv efter døden. Den tapre død gav ikke vis- 
hed om et liv hinsides. Den gode gerning var en belønning i sig selv. Dog nævner Seneca, at de kloge sjæle skal adskilles og leve evigt, og dette giver Bartholin anledning til at drage sammenligning med den nordiske mytologi, hvor kun de tapre kom til Valhal og levede evigt. Han citerer Regner Lodbrogs stolte ord: "Eigi kam ek med ædru Ord til Vidris hallar". Og i Njals Saga siger Gudbrand, at guderne hævner ikke alt straks, men den, som havde begået den udåd at brænde gudehuset, ville blive drevet ud af Valhal og aldrig komme dér.

Anden bog afsluttes med profetien om jordens undergang, som den optræder i Eddaen. Bartholin fremhæver, at forudsigelsen om jordens undergang også forekommer i Biblen, i Peters Andet Brev 3.10 :"Men Herrens dag skal komme som en tyv; da skal himlene forgå med et brag, elementerne skal komme i brand og opløses, og jorden og alt menneskeværk på den skal brændes op".

I Ovids Forvandlinger, første sang, står der om syndfloden:

"Han husker også, det står i skæbnen, at tider skal komme, hvor hav og hvor jord og hvor gudernes hjem skal bryde i flammer, verdensbygningens vælde fortæres og synke i aske".

(Oversætt. Otto Steen Due).

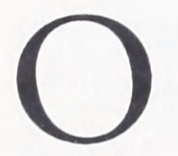

g også Seneca henviser til verdensbranden i 3. bog af Naturfilosofien, og ligeledes i slutningen af Trostekrift til Marcia skriver han, at jorden vil gå til grunde ved en verdensbrand og derefter indtræde i en ny tilstand?.

Bartholin citerer hele den sidste deł af Volvens Spådom med den sublime skildring af ragnarok, hvor solen sortner, og jorden synker i havet. Spådommen klinger ud i skildringen af den nye verden, som rejser sig af havet evig grøn. Aserne samles igen på Ide-sletten, og de gyldne tavl findes atter i græsset. Balder vender tilbage, og gyldent tækket står Gimles sal.

Bartholins tekst er i overensstemmelse med de bedste overleveringer, hvad der sikkert er Arni Magnussons fortjeneste. Han har tilføjet strofen fra Hauksbok-håndskriftet:

Kommer herlig Stor -Herskeren Stærk fra oven, Alt han styrer Dom han siger, Strid han stiller, Fæstner Vedtægt, som være vil. (Karl Gjellerups oversættelse).

Strofen anses ikke for at være oprindelig, da den giver udtryk for en kristen forestilling. Dog er der flere bibelske elementer i Volvens Spådom, som kunne tyde på, at digteren har kendt til den kristne lære. Som Bartholin påpeger, er der ligeledes stor overensstemmelse mellem stoikernes tro på verdensbranden og beskrivelsen af jordens undergang i Volvens Spådom, hvilket ligeledes kunne tolkes som tegn på en fælles oprindelse.

Strofen fra Hauksbok om Stor

Herskeren, som styrer og fælder dom over menneskeslægten, peger frem mod den sidste årsag til danernes dødsforragt, nemlig deres skæbnetro. Dette er emnet for 3. bog. I første kapitel citerer Bartholin det centrale citat af Aulus Gellius fra Chrysippusfragmentet, hvor Chrysippus kalder skæbnen en åndelig kraft, der styrer verden i en bestemt uforanderlig og uforgængelig orden.

Skæbnebegrebet og troen på skæbnen var et kontroversielt filosofisk emne i det 17. århundrede. Justus Lipsius 
måtte i sine filosofiske værker om stoicismen og Seneca fra begyndelsen af 1600 modificere den stoiske filosofi af hensyn til kristendommen. Han frikendte Seneca for at underordne Gud under fatum og indførte den læresætning, at fatum var lig med det forsyn, som kom til udtryk i den enkeltes liv og begivenheder.

I den calvinistiske tro, som Bartholin refererer til, spillede forsynet en væsentlig rolle. Men Calvin afviste den stoiske forsynstro og talte alene om Gud.

En kommentar af den lærde Brynjólfur Sveinsson i Stephanius' Note Uberiores til Saxos 1. bog fremhæves af Bartholin. Her skriver Brynjólfur, at troen på den uafvendelige skæbne var fælles for stoikere og nordboer; hverken kløgt eller tapperhed kunne afvende skæbnen.

Bartholin citerer slutningen af det kvad, som den dødeligt sårede Hildinger fremsiger i Saxos 7. bog, som et eksempel på skæbnens magt i den nordiske folketro.

Ja, ussel er Lodden Thi Stamp i mod Brodden

Ei baader et Straa;

Mod Nornernes Runer, Mod Nornernes Luner, Kan ingen bestaa.

Det være en Hjerne

Høiviis i det Fjerne, som styre vor Vei;

Det være en Orden,

Sig villes lig vorden, Vi ændre det ei!

(Grundtvigs oversættelse). ${ }^{10}$

Odin fastlagde det enkelte menneskes skæbne, og de tre skæbnegudinder forvaltede den, skriver Bartholin i indled- ningen til 3. bog. Han fremdrager mange eksempler herpå fra den norrøne litteratur, f.eks. stroferne fra Vølvens Spådom, hvor nornerne Verd, Verdandi og Skuld vander asken Yggdrasil med det hvide dynd fra Urds brønd, så det hellige træ ikke skal gå ud. I teksten beskrives nornerne således:

Al lov bød de

alt liv gav de

verdens skare hver hans skæbne. ${ }^{11}$

Spådomme spillede en stor rolle i den norrøne litteratur, ligesom i den antikke. Det er et tema, som er tæt knyttet til skæbnemotivet, og også her finder Bartholin grundlag for at bygge bro mellem de to litteraturer. Flere digte med orakelmotiv gengives i deres helhed i 3 . bog, således f.eks. Vegtams Qvida.

Bartholin konkluderer i slutningen af 3. bog, at den nordiske stoicisme var en god teologi for soldater; thi når alt var fastlagt på forhånd, var der ingen grund til at unddrage sig fare i krig.

Grænsen mellem politik, religion og filosofi var flydende i det 17. århundrede. Vi får et indblik i, hvorledes samtiden opfattede Bartholins værk gennem en anmeldelse i tidsskriftet Bibliotheque Universelle. Her skriver anmelderen i slutningen af anmeldelsen efter en omhyggelig gennemgang af alle tre bøger $\mathrm{i}$ Antiquitatem Danicarum 12: "Voilà une bonne raison de Politique pour engager les Princes à faire enseigner par tout la Philosophie Stoïque".

Med sit store værk om danernes heltemod var det Bartholins hensigt ikke kun at vise omverdenen, at danskerne havde en fortid, som kunne måle sig med den romerske og græske oldtid, men ligeledes at skabe en filosofisk basis for ændringer i mentale holdninger i samtiden. 
Med forskeren som vejleder var det magtpåliggende for fyrsteadministrationen (som Bartholin tilhørte) at indføre de romerske doktriner om pligt og dyd som en sækulariseret modpart til kirkemagten.

Bartholin døde året efter udgivelsen af Antiquitatem Danicarum, svækket af tuberkulose og overanstrengelse. Det var den 5. november 1690. Han blev kun 31 år, men han efterlod sig 25 foliobind historiske og især kirkehistoriske håndskrifter til eftertiden.

Hans mål var at skrive en dansk kirkehistorie i lighed med de store katolske kirkehistoriske værker ved hjælp af disse værdifulde kildeskrifter, som nu opbevares i Det kongelige Biblioteks Håndskriftsafdeling.

Noter:

1. Antiquitatem Danicarum de causis contempto a Danis adhuc gentilibus mortis libri tres, ex vetustis codicibus et monumentis hactenus ineditis congesti. Hafniæ: 1689.

2. Lars Lönnroth: Ideologi och samhällssyn i de isländska sagorna. I: Nordatlantiske foredrag, Tórshavn: 1991, s.111.

3. Marianne Alenius: Seneca-oversætteren Birgitte Thott: Et fagligt portræt. I: Danske Studier, Kbh.: 1983, s. 20 f.

4. Antiquitatem: s. 28.

5. Isländska mytsagor Översatta och kommenterade av Lars Lönnroth. Stockholm: 1995, s. 13.

6. Sst. s. 42.

7. Antiquitatem: 2. bog, kap. II og III.

8. Sst. s. 285.

9. Antiquitatem. s. 589.

10. Sst. s. 608.

11. Sst. s. 611.

12. Bibliothèque Universelle et Historique, Amsterdam: 1686-1693; vol XV, s. 398.
Litteratur:

Abel, Günter: Stoizismus und Frühe Neuzeit, Berlin: 1978.

Acta eruditorum, Leipzig: 1689, s. 625-34; 1690, s. 27-35. (Anmeldelse).

Banning, Knud: Justus Lipsius, Kbh.: 1975.

Bartholin, Thomas: Dansk oversættelse af noget af hans Antiquitatem Danicarum, Ny kgl.S. 4to 637.

Bartholin, Thomas: Index til Bartholins Antiquitatem, Ny kgl.S. 4to 638.

Chew, Audrey: Stoicism in Renaissance English Literature, New York: 1988.

Dansk biografisk leksikon / red: Sv. Cedergreen Bech, Kbh.: 1979-84.

Ehrencron-Müller, H.: Forfatterlexikon, Kbh.: 1924-35.

Finnur Jónsson: Udsigt over den norsk-islandske filologis historie, Kbh.: 1918.

A History of Nordic Neo-Latin Literature / ed. by Minna Skafte Jensen, Odense: 1995.

Holland Danmark: Forbindelsen mellem de to lande gennem tiderne / red. af Knud Fabricius, L.L. Hammerich og Vilh. Lorentzen, Kbh.: 1945; bind 2, kap. VI.

Jørgensen, Ellen: Historieforskning og historieskrivning i Danmark indtil aar 1800, Kbh.: 1964.

Kobenhavns Universitet 1479-19791 hovedredaktion: Svend Ellehøj, Kbh.: 1979; bind IX.

Oestreich, Gerhard: Neostoicism and the early modern state, Cambridge: 1982.

Petersen, Jul.: Bartholinerne og Kredsen om dem, Kbh.:1898.

Saunders, Jason Lewis: Justus Lipsius: The Philosophy of Renaissance Stoicism, New York: 1955.

Seneca: Moral essays, vol. 1, Cambridge: 1970.

Seneca : Naturales Quaestiones, Vol. 1-2, London: 1971.

Seneca: Om vrede; $O m$ mildhed; Om sindsro I på dansk ved Villy Sørensen, Kbh.: 1995.

Sørensen, Villy: Seneca: Humanisten ved Neros hof, Kbh.: 1995. 